\title{
PULMONARY FUNCTION STUDIES IN MITRAL STENOSIS BE- FORE AND AFTER COMMISSUROTOMY
}

\author{
BY M. HENRY WILLIAMS, JR. \\ (From the Department of Cardiorespiratory Diseases, Walter Reed Army Medical Center, \\ Army Medical Service Graduate School, Washington, D. C.)
}

(Submitted for publication May 7, 1953; accepted July 1, 1953)

Decreased arterial oxygen saturation may occur in the blood of patients with mitral stenosis. This unsaturation might be due to impairment of diffusion of oxygen across the alveolar membrane or to impairment of ventilation-perfusion relationships in the lung. Both such abnormalities have been found in patients with mitral stenosis $(1,2,3)$, but it is highly unlikely that appreciable unsaturation could occur during the breathing of room air as a result of impaired diffusion. This report deals with the pulmonary diffusing capacity and ventilation-perfusion relationships in nine patients with mitral stenosis before and after mitral commissurotomy.

\section{MATERIAL AND METHODS}

The patients were from the wards of Walter Reed Army Hospital and demonstrated evidence of uncomplicated mitral stenosis which had led to progressive dyspnea and/ or hemoptysis. In each instance the diagnosis was confirmed at the time of commissurotomy.

The patients were studied in the fasting state during the inspiration of room air and a low oxygen mixture. Expired air was collected for a three-minute interval in the midst of which arterial blood was allowed to flow from an indwelling radial arterial needle for a one-minute period into a syringe containing mercury and a minimum of heparin. Arterial gas tensions were measured immediately by the direct method of Riley, Proemmel, and Franke (4) which has been standardized in this laboratory (5). Expired gas volumes were measured in a Tissot spirometer and the composition was measured by means of the Scholander micro-gas analyzer (6). Alveolar oxygen tension was calculated from the alveolar equation, substituting the arterial $\mathrm{pCO}_{2}$ for the alveolar $\mathrm{pCO}_{2}$. The oxygen diffusing capacity $\left(\mathrm{DO}_{2}\right)$ and the percentage venous admixture (Q்va/Q்t) as defined in the expanded sense by Riley and Cournand $(7,8)$ were calculated, assuming a 25 per cent difference in saturation between end-capillary and mixed venous blood $\left(P^{\bullet}-P_{v}\right)$. In Cases 4 and 5 a 30 per cent difference in saturation was assumed because of the large amount of venous admixture.

\section{RESULTS}

The results of these studies are presented in Table I. In normal subjects, not shown here, the venous admixture averages 3 per cent, varying from 0-8 per cent. Also, in normal subjects, the alveolar-arterial oxygen gradient during the inspiration of a low oxygen mixture is negligible so that the lower limit of normal for $\mathrm{Do}_{2}$ has arbitrarily been selected as 20 (9). Since the methods employed do not measure gradients with an accuracy of more than $3-4 \mathrm{~mm}$. $\mathrm{Hg}$, and since accurate calculation of the diffusing capacity is impossible in the presence of small gradients, $\mathrm{DO}_{2}$ is simply listed as "normal" if the effective alveolarend-capillary gradient $\left(\mathrm{P}_{\mathbf{A}}{ }_{4}-\mathrm{P}^{\circ} \mathrm{CO}_{2}\right)$ during the inspiration of the low oxygen mixture is less than 4 $\mathrm{mm}$. $\mathrm{Hg}$. In all but three patients the per cent venous admixture was increased, ranging from 818 per cent. In all but one instance this became normal after pulmonary congestion was relieved by commissurotomy. Since the arteriovenous difference may become less after operation, and since the estimated amount of venous admixture would err by 3 per cent if the arteriovenous difference varied by 10 per cent from the assumed value, only a change in venous admixture of over 3 per cent may be considered significant. Thus, four out of the six patients with increased venous admixture preoperatively showed a significant fall after operation.

Five of the patients showed resting hyperventilation which, in four, disappeared after commissurotomy. In the patient (Case 7) in whom the hyperventilation and elevated venous admixture effect persisted there was indication of psychological abnormality such that the hyperventilation appeared to have been functional and may account for part of the increase in venous admixture (5).

Oxygen diffusing capacity was not measured in three of the patients preoperatively. In the others, it was reduced in two instances. In Case 2 there was a postoperative increase in diffusing capacity whereas diffusing capacity fell postoperatively in Case 1. The other patients showed slight or no change in this function. 
TABLE I

Physiological data on patients with mitral stenosis pre- and post-operatively

\begin{tabular}{|c|c|c|c|c|c|c|c|c|c|c|c|c|c|c|c|}
\hline Case & Age & $\begin{array}{l}\text { B.S.A. } \\
\text { sq.m. }\end{array}$ & Sex & $\begin{array}{l}\text { Pre or } \\
\text { postop. }\end{array}$ & $\begin{array}{c}\mathrm{P}_{\mathrm{I}_{\mathrm{O}}} \\
\mathrm{mm} . \\
\mathrm{Hg}\end{array}$ & $\begin{array}{c}\mathrm{P}_{\text {moog }} \\
m m_{2} \\
\mathrm{Hg}\end{array}$ & $\begin{array}{c}\mathrm{P}_{\mathrm{aO}_{2}} \\
\mathrm{~mm} . \\
\mathrm{Hg}\end{array}$ & $\mathbf{R}$ & $\begin{array}{c}\dot{\mathrm{V}} \\
\text { B./min. } \\
\text { BTPS }\end{array}$ & $\begin{array}{c}\mathrm{P}_{\mathbf{A}_{\mathbf{O}}} \\
\mathrm{mm}_{\mathrm{m}} \\
\mathrm{Hg}\end{array}$ & $\begin{array}{c}\mathrm{P}_{\mathbf{C}_{\mathrm{O}_{2}}} \\
\mathrm{~mm}_{\mathrm{m}} \\
\mathrm{Hg}\end{array}$ & $\begin{array}{l}\dot{Q} v a / \text { Q́t.t. } \\
\times 100\end{array}$ & $\begin{array}{c}\mathrm{D}_{\mathrm{o}_{2}} \\
\text { cc./min./ } \\
\text { mm. }\end{array}$ & $\underset{\times 100}{\text { D.S./TV }}$ & $\begin{array}{l}\dot{\mathrm{V}}_{\mathrm{Oz}} \\
L . / \mathrm{min} . \\
\text { STPD }\end{array}$ \\
\hline 1 & 41 & & $\mathbf{M}$ & $\begin{array}{l}\text { Preop. } \\
3 \text { weeks } \\
\text { postop. }\end{array}$ & $\begin{array}{r}146 \\
146 \\
95 \\
148 \\
96\end{array}$ & $\begin{array}{l}30 \\
30 \\
30 \\
34 \\
34\end{array}$ & $\begin{array}{l}89 \\
84 \\
53 \\
95 \\
49\end{array}$ & $\begin{array}{l}.84 \\
.88 \\
.86 \\
.91 \\
.94\end{array}$ & $\begin{array}{l}7.02 \\
8.03\end{array}$ & $\begin{array}{r}112 \\
113 \\
62 \\
111 \\
60\end{array}$ & $\begin{array}{r}112 \\
113 \\
59 \\
111 \\
51\end{array}$ & $\begin{array}{c}9 \\
13 \\
(13) \\
6 \\
(6)\end{array}$ & $\begin{array}{c}\text { Normal } \\
11\end{array}$ & $\begin{array}{l}10 \\
19\end{array}$ & $\begin{array}{l}210 \\
202\end{array}$ \\
\hline 2 & 18 & 1.38 & F & $\begin{array}{l}\text { Preop. } \\
12 \text { weeks } \\
\text { postop. }\end{array}$ & $\begin{array}{r}150 \\
97 \\
100 \\
149\end{array}$ & $\begin{array}{l}34 \\
30 \\
40 \\
42\end{array}$ & $\begin{array}{l}88 \\
48 \\
46 \\
91\end{array}$ & $\begin{array}{l}.73 \\
.90 \\
.70 \\
.72\end{array}$ & $\begin{array}{r}9.04 \\
10.95 \\
7.86 \\
5.52\end{array}$ & $\begin{array}{r}106 \\
64 \\
45 \\
94\end{array}$ & $\begin{array}{r}105 \\
50 \\
45 \\
94\end{array}$ & $\begin{array}{c}8 \\
(8) \\
(2) \\
2\end{array}$ & $\stackrel{9}{\text { Normal }}$ & $\begin{array}{l}34 \\
39 \\
33 \\
30\end{array}$ & $\begin{array}{l}253 \\
221 \\
259 \\
206\end{array}$ \\
\hline 3 & 19 & 1.75 & $\mathbf{M}$ & $\begin{array}{l}\text { Preop. } \\
7 \text { weeks } \\
\text { postop. }\end{array}$ & $\begin{array}{r}148 \\
96 \\
149 \\
100 \\
71\end{array}$ & $\begin{array}{l}37 \\
34 \\
37 \\
37 \\
28\end{array}$ & $\begin{array}{l}94 \\
52 \\
92 \\
50 \\
37\end{array}$ & $\begin{array}{r}.81 \\
.92 \\
.84 \\
.83 \\
1.01\end{array}$ & $\begin{array}{l}6.48 \\
7.63 \\
5.67 \\
5.72 \\
9.26\end{array}$ & $\begin{array}{r}104 \\
59 \\
106 \\
56 \\
43\end{array}$ & $\begin{array}{r}104 \\
54 \\
106 \\
52 \\
37\end{array}$ & $\begin{array}{c}5 \\
(5) \\
6 \\
(6) \\
(6)\end{array}$ & $\begin{array}{l}16 \\
15 \\
20\end{array}$ & $\begin{array}{l}19 \\
14 \\
16 \\
18 \\
15\end{array}$ & $\begin{array}{l}241 \\
247 \\
206 \\
198 \\
222\end{array}$ \\
\hline 4 & 38 & 1.58 & $\mathbf{F}$ & $\begin{array}{l}\text { Preop. } \\
2 \frac{1}{2} \text { weeks } \\
\text { postop. }\end{array}$ & $\begin{array}{r}148 \\
148 \\
149 \\
97\end{array}$ & $\begin{array}{l}32 \\
32 \\
37 \\
31\end{array}$ & $\begin{array}{l}73 \\
57 \\
83 \\
53\end{array}$ & $\begin{array}{l}.78 \\
.70 \\
.80 \\
.91\end{array}$ & $\begin{array}{l}9.27 \\
9.72 \\
5.41\end{array}$ & $\begin{array}{r}109 \\
105 \\
105 \\
66\end{array}$ & $\begin{array}{r}109 \\
105 \\
105 \\
58\end{array}$ & $\begin{array}{c}17 \\
33 \\
11 \\
(11)\end{array}$ & 8 & $\begin{array}{l}38 \\
40 \\
28\end{array}$ & $\begin{array}{l}230 \\
251 \\
173 \\
163\end{array}$ \\
\hline 5 & 27 & 1.52 & $\mathbf{F}$ & $\begin{array}{l}\text { Preop. } \\
3 \text { weeks } \\
\text { postop. }\end{array}$ & $\begin{array}{l}148 \\
148 \\
149 \\
149 \\
101\end{array}$ & $\begin{array}{l}37 \\
38 \\
42 \\
43 \\
36\end{array}$ & $\begin{array}{l}68 \\
70 \\
84 \\
78 \\
39\end{array}$ & $\begin{array}{r}.90 \\
.86 \\
.89 \\
.85 \\
1.20\end{array}$ & $\begin{array}{l}8.26 \\
7.96 \\
6.76 \\
6.75 \\
9.47\end{array}$ & $\begin{array}{r}108 \\
105 \\
103 \\
100 \\
70\end{array}$ & $\begin{array}{r}100 \\
95 \\
92 \\
88 \\
39\end{array}$ & $\begin{array}{c}18^{*} \\
15^{*} \\
5 \\
7 \\
(7)\end{array}$ & 4 & $\begin{array}{l}32 \\
32 \\
33 \\
36 \\
38\end{array}$ & $\begin{array}{l}214 \\
227 \\
190 \\
191 \\
165\end{array}$ \\
\hline 6 & 35 & 1.76 & $\mathbf{F}$ & 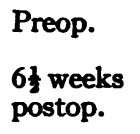 & $\begin{array}{r}149 \\
101 \\
148 \\
70\end{array}$ & $\begin{array}{l}39 \\
37 \\
34 \\
29\end{array}$ & $\begin{array}{l}90 \\
62 \\
90 \\
39\end{array}$ & $\begin{array}{l}.75 \\
.92 \\
.70 \\
1.00\end{array}$ & $\begin{array}{l}5.54 \\
5.98 \\
5.54 \\
6.22\end{array}$ & $\begin{array}{r}100 \\
61 \\
102 \\
41\end{array}$ & $\begin{array}{r}100 \\
64 \\
102 \\
40\end{array}$ & $\begin{array}{c}5 \\
(5) \\
6 \\
(6)\end{array}$ & $\begin{array}{l}\text { Normal } \\
\text { Normal }\end{array}$ & $\begin{array}{l}23 \\
23 \\
18 \\
22\end{array}$ & $\begin{array}{l}232 \\
204 \\
213 \\
117\end{array}$ \\
\hline 7 & 25 & 1.38 & $\mathbf{F}$ & $\begin{array}{l}\text { Preop. } \\
5 \text { weeks } \\
\text { postop. }\end{array}$ & $\begin{array}{r}148 \\
148 \\
97 \\
149\end{array}$ & $\begin{array}{l}30 \\
32 \\
31 \\
30\end{array}$ & $\begin{array}{l}92 \\
90 \\
52 \\
87\end{array}$ & $\begin{array}{l}.80 \\
.81 \\
.81 \\
.73\end{array}$ & $\begin{array}{l}7.25 \\
6.52 \\
7.47 \\
8.26\end{array}$ & $\begin{array}{r}112 \\
110 \\
60 \\
110\end{array}$ & $\begin{array}{r}112 \\
110 \\
56 \\
110\end{array}$ & $\begin{array}{c}8 \\
9 \\
(10) \\
10\end{array}$ & 14 & $\begin{array}{l}25 \\
25 \\
29 \\
25\end{array}$ & $\begin{array}{l}192 \\
181 \\
191 \\
199\end{array}$ \\
\hline 8 & 41 & 1.47 & $\mathbf{F}$ & $\begin{array}{l}\text { Preop. } \\
3 \frac{1}{1} \text { weeks } \\
\text { postop. }\end{array}$ & $\begin{array}{r}101 \\
149 \\
149 \\
100 \\
71\end{array}$ & $\begin{array}{l}36 \\
37 \\
38 \\
36 \\
31\end{array}$ & $\begin{array}{l}55 \\
96 \\
92 \\
57 \\
35\end{array}$ & $\begin{array}{l}.98 \\
.80 \\
.83 \\
.90 \\
.97\end{array}$ & $\begin{array}{l}7.70 \\
6.76 \\
4.64 \\
7.11 \\
8.51\end{array}$ & $\begin{array}{r}61 \\
105 \\
105 \\
60 \\
39\end{array}$ & $\begin{array}{r}58 \\
105 \\
105 \\
60 \\
35\end{array}$ & $\begin{array}{l}(4) \\
4 \\
6 \\
(6) \\
(6)\end{array}$ & $\begin{array}{l}\text { Normal } \\
\text { Normal } \\
23\end{array}$ & $\begin{array}{l}30 \\
28 \\
21 \\
26 \\
26\end{array}$ & $\begin{array}{l}162 \\
182 \\
113 \\
180 \\
185\end{array}$ \\
\hline 9 & 24 & 1.86 & $\mathbf{M}$ & $\begin{array}{l}\text { Preop. } \\
3 \text { weeks } \\
\text { postop. }\end{array}$ & $\begin{array}{r}148 \\
100 \\
149 \\
90\end{array}$ & $\begin{array}{l}33 \\
33 \\
36 \\
37\end{array}$ & $\begin{array}{l}89 \\
51 \\
90 \\
42\end{array}$ & $\begin{array}{l}.84 \\
.78 \\
.73 \\
.78\end{array}$ & $\begin{array}{l}8.66 \\
8.01 \\
6.67\end{array}$ & $\begin{array}{r}110 \\
59 \\
103 \\
43\end{array}$ & $\begin{array}{r}110 \\
54 \\
103 \\
43\end{array}$ & $\begin{array}{c}9 \\
(9) \\
6 \\
(6)\end{array}$ & $\begin{array}{c}20 \\
\text { Normal }\end{array}$ & $\begin{array}{l}21 \\
24 \\
20\end{array}$ & $\begin{array}{l}261 \\
297 \\
250 \\
263\end{array}$ \\
\hline
\end{tabular}

* $\mathrm{P}_{\mathbf{A}}-\mathrm{P}_{\mathrm{C}_{\mathrm{O}}}$ of 37 assumed for calculation of per cent venous admixture, since that was the mean alveolar-capillary gradient determined postoperatively.

\section{DISCUSSION}

Certain effects of longstanding mitral stenosis are apparent from these studies. As reported also by others $(2,3)$ the pulmonary diffusing capacity for oxygen is frequently reduced, although usually not greatly enough to cause an alveolar-arterial oxygen gradient during the inspiration of room air. Four of our patients showed a very low oxygen diffusing capacity postoperatively, but in only one instance (Case 5) did the impaired diffusion cause an appreciable alveolar-arterial gradient during the breathing of room air. This impairment is not likely to be greatly improved by commissurotomy and may be attributed either to thickening of the alveolar capillaries, as has been shown to occur in mitral stenosis (10) or to reduction in the size of the effective pulmonary capillary bed.

The impaired distribution of blood and gas in 
the lung, which is largely eliminated by reduction of the pulmonary hypertension, may be attributed to pulmonary congestion with effective blocking of the small airways by transudate. A similar effect has been observed in experimental pulmonary edema (11), in which there is a large venous admixture effect but no impairment of diffusion across the alveolar membrane. Prolonged rest in the supine position is apt to increase the pulmonary congestion. This is exemplified by Case 4 in whom the venous admixture increased from $17-33$ per cent as the patient developed mild dyspnea after lying supine for one hour. There was a good correlation between the size of the venous admixture effect and the clinical symptomatology.

The frequent occurrence of resting hyperventilation which disappears after commissurotomy suggests that the engorged pulmonary bed serves as a reflex stimulus to ventilation.

Ventilatory studies were performed on these patients and revealed normal or slightly reduced maximum breathing capacity and vital capacity in each case. Only in the patient with a 33 per cent venous admixture effect was the lung dead space greatly increased ( 40 per cent of the tidal volume), and this fell postoperatively. A large dead space effect would be expected when large numbers of alveoli are not effectively ventilated. The small increase in dead space in Cases 2 and 5 was not significantly changed postoperatively.

\section{SUMMARY}

Pulmonary function has been studied in nine cases of mitral stenosis before and after commissurotomy. Several cases showed an increase in the effective shunting of venous blood through unaerated or poorly ventilated lung with, in some instances, arterial unsaturation. This abnormality was largely corrected by commissurotomy. Pulmonary diffusing capacity was frequently impaired, little affected by operation but usually not sufficiently reduced to cause lowering of arterial oxygen tension during the breathing of room air. Resting hyperventilation, when due to pulmonary congestion, was diminished after commissurotomy.

\section{ACKNOWLEDGMENTS}

The cooperation of Col. Thomas W. Mattingly in securing these patients for study is gratefully acknowledged.

\section{REFERENCES}

1. Blount, S. G., Jr., McCord, M. C., and Anderson, L. L., The alveolar-arterial oxygen pressure gradient in mitral stenosis. J. Clin. Invest., 1952, 31, 840.

2. Carrol, D., and Riley, R. L., Pulmonary vascular function in mitral stenosis. J. Clin. Invest., (Abstract.), 1952, 31, 620.

3. Blount, S. G., Jr., McCord, M. C., Anderson, L. L., and Komesu, S., The oxygen diffusion capacity of the alveolar-capillary membrane in mitral stenosis. J. Lab. \& Clin. Med., 1952, 40, 782.

4. Riley, R. L., Proemmel, D. D., and Franke, R. E., A direct method for determination of oxygen and carbon dioxide tensions in blood. J. Biol. Chem., 1945, 161, 621.

5. Williams, M. H., Jr., Alveolar-arterial oxygen pressure gradient in normal dogs. Am. J. Physiol., 1953, 173, 77.

6. Scholander, P. F., Analyzer for accurate estimation of respiratory gases in one-half cubic centimeter samples. J. Biol. Chem., 1947, 167, 235.

7. Riley, R. L., and Cournand, A., Analysis of factors affecting partial pressures of oxygen and carbon dioxide in gas and blood of lungs: Theory. J. Applied Physiol., 1951, 4, 77.

8. Riley, R. L., and Cournand, A., Analysis of factors affecting partial pressures of oxygen and carbon dioxide in gas and blood of lungs: Methods. J. Applied Physiol., 1951, 4, 102.

9. Williams, M. H., Jr., Unpublished data.

10. Parker, F., Jr., and Weiss, S., The nature and significance of the structural changes in the lungs in mitral stenosis. Am. J. Path., 1936, 12, 573.

11. Williams, M. H., Jr., Effect of antu-induced pulmonary edema on the alveolar-arterial oxygen gradient in dogs. Federation Proc., 1953, 12, 487. 